\title{
Relations between nutrients and bioactive compounds of commercial tomato varieties by the Principal Component Analysis
}

\author{
Marcy Heli Paiva RODRIGUES ${ }^{1}$, Larine KUPSKI ${ }^{1}$, Taiana Denardi de SOUZA ${ }^{1}$, Jean Lucas de Oliveira ARIAS ${ }^{2}$, \\ Marcelo Montes D’OCA², Eliana Badiale FURLONG ${ }^{1 *}$ (iD
}

\begin{abstract}
This study evaluated relations among nutrients, bioactive compounds and antioxidant activity of commercial tomato varieties grown in field conditions in order to identify their biological potential by the Principal Component Analysis (PCA). Four commercial tomato varieties (Long Life, Italian, Khaki and Cherry), homogenized by their maturation stage (color, sugar/acidity ratio and $\mathrm{pH}$ ) were evaluated regarding macro components (sugars, pectin and minerals) and functional ones (carotenoids, phenolic compounds and ascorbic acid). Cherry tomatoes stood out for their pectin and lycopene contents and their sugar/ acidity ratio. Tomato samples were good sources of $\mathrm{Cu}$ and $\mathrm{Ca}$. The PCA showed that the antioxidant potential of phenolic compounds was related to protocatecoic acid and quercetin concentrations. Italian and Cherry varieties stood out for their carotenoid contents. In field conditions, Cherry and Italian tomatoes were the best sources of functional compounds among the most common varieties found in the human diet.
\end{abstract}

Keywords: ascorbic acid; carotenoids; macro components; phenolic compounds; protocatecoic acid.

Practical Application: This work provides subsidies for traceability of tomatoes and claiming of functionality of the tomato varieties.

\section{Introduction}

Antioxidant mechanisms of fruit are constituted by enzymes and chemical groups that are able to prevent, inactivate and avoid propagation of free radicals, which also determine their positive effect on human diet (Borguini \& Silva Torres, 2009; Ulewicz-Magulska \& Wesolowski, 2019). Tomatoes (Solanum lycopersicum) are fruit that have been known as a good source of bioactive compounds, whose effects are related to antioxidant activity of carotenoids (lycopene and $\beta$ carotene), phenolic compounds (phenolic acids and flavonoids) and ascorbic acid (Coyago-Cruz et al., 2019) with anticarcinogenic, antimicrobial, antimutagenic and anti-inflammatory properties (GarcíaHernández et al., 2018; Navarro-González et al., 2018). The supply chain has maintained tomato varieties that grow well at moderate temperatures ranging from 18 to $25^{\circ} \mathrm{C}$, low relative humidity and low rainfall from 5 to 6 consecutive months (Vallverdú-Queralt et al., 2012).

Tomato varieties, as well as other crop species, have been genetically modified to improve productivity, functionality and resistance to endogenous and exogenous damage, to be consumed in natura and in processed forms (Asensio et al., 2019). Consequently, fruit varieties differ regarding their profiles of secondary metabolites, which are responsible for the defence mechanism and biological stage differentiation. They are important factors to be taken into account in the evaluation of the role that these fruit play in human health (García-Hernández et al., 2018; Huang et al., 2005). Studies of genetic improvement effects on tomato nutritional and functional properties have been conducted by controlled experiments (Coyago-Cruz et al., 2019; Fattore et al., 2016; Li et al., 2017). However, genetic characteristics are affected by environmental and natural crop management. Since in some production regions climate conditions are unpredictable, their effects on nutrients and functional compounds in tomatoes need to be evaluated to highlight their benefits and prevent damage to human health.

The ability of a tomato variety grown in field conditions and available in markets to promote benefits to health can be determined by the profile of its bioactive chemical families (Borguini \& Silva Torres, 2009; Choi et al., 2014; Coyago-Cruz et al., 2019). To evaluate its antioxidant potential by different procedures and to relate all factors by multivariate statistical techniques, such as the Principal Component Analysis (PCA), enable to identify the main chemical family which is responsible for the antioxidant potential. The PCA is a good tool to compare food matrices, analytical procedures and bioactive potential (Granato et al., 2017). It consists in representing relations among samples and variables graphically and results in new variables that are the main components to explain data variability and correlation. Therefore, it is a good tool to better know about the specific efficiency of tomato varieties to prevent diseases caused by oxidative damage (Huang et al., 2005; Navarro-González et al., 2018). This study aimed at evaluating relations among nutrients, bioactive compounds and antioxidant activity of commercial tomato varieties grown in field conditions in order to identify their real biological potential by the PCA.

${ }^{1}$ Laboratório de Micotoxinas e Ciência de Alimentos, Escola de Quimica e Alimentos, Universidade Federal do Rio Grande - FURG, Rio Grande, RS, Brasil

${ }^{2}$ Centro Integrado de Análises, Universidade Federal do Rio Grande - FURG, Rio Grande, RS, Brasil

*Corresponding author: dqmebf@furg.br 


\section{Materials and methods}

\subsection{Tomato samples and their physical-chemical properties}

Tomato varieties Cherry, Khaki, Long Life and Italian were grown in field conditions in southern Brazil. Samples were randomly collected every two months for a year. A kilogram of every fruit variety was chosen by size, color and texture in markets where there was great rotation of products. Moisture, pectin, color, acidity and soluble sugars were determined in fruit in natura. Maturation stage uniformity of analytical samples of every variety to determine functional compounds was established by color, $\mathrm{pH}$ and sugar/acidity ratio. Fruit in the maturation stage were comminuted, lyophilized in a freeze dryer (Liotop, Model L101) and stored at $-4{ }^{\circ} \mathrm{C}$ until bioactive chemical group experiments were performed.

Color analysis was carried out by a Minolta ${ }^{\circledR}$ CR 400 colorimeter and determined by following the color system in space $a^{*} b^{*}$ or CIE- $L^{*} a^{*} b^{*}$, defined by the International Commission on Illumination (ICI) in 1976 (Commission Internationale de l'Eclairage, 1986). The $\mathrm{pH}$ was measured by a potentiometer (Hanna Instruments, Romania) with a glass electrode. Titratable acidity was determined by volumetry and expressed as grams of oxalic acid (Association of Official Analytical Chemists, 2000). Soluble and insoluble fractions of pectin were determined by the gravimetric method described by McCready \& McComb (1952).

Determination of moisture, ash and protein contents followed procedures issued by the Association of Official Analytical Chemists (2000). Profiles of calcium, iron, copper and manganese were determined by atomic absorption spectrometry (Watanabe et al., 2015). To carry it out, $300 \mathrm{mg}$ lyophilized tomato was digested by a digestor block at $130{ }^{\circ} \mathrm{C}$ for $3 \mathrm{~h}$ with $3 \mathrm{~mL}$ nitric acid and $1 \mathrm{~mL}$ hydrogen peroxide. The volume was made up to $25 \mathrm{~mL}$ before absorbance reading by an atomic absorption spectrometer (Perkin Elmer, Model A Analyst 800). Ca, Fe, $\mathrm{Cu}$ and $\mathrm{Mn}$ standards were obtained from Sigma Aldrich and used to establish the standard curve model at their respective wavelengths: 422, 248, 324 and $279 \mathrm{~nm}$.

Soluble sugars were determined in two hundred mg lyophilized tomato was weighed and mixed with $5 \mathrm{~mL}$ distilled water under vortexing and sonicated for $5 \mathrm{~min}$. The mixture was centrifuged at $3660 \times g$ for $7 \mathrm{~min}$, filtered by a $0.45 \mu \mathrm{m}$ Millipore filter (Agilent Technologies) (Coyago-Cruz et al., 2017) and analysed by an HPLC apparatus (Shimadzu, Tokyo, Japan, RID-10A) coupled with a refractive index detector with an Aminex HPX87H column $(300 \mathrm{~mm} \times 7.8 \mathrm{~mm}, 9 \mathrm{~m})$. The system operated at a flow rate of $0.6 \mathrm{~mL} \cdot \mathrm{min}^{-1}$ at $65^{\circ} \mathrm{C}$ by using $5 \mathrm{mM}$ sulphuric acid as the mobile phase. Identification of sugars in samples was performed with retention time of reference standards (Sigma Aldrich): glucose, fructose, sucrose and arabinose (Johnston \& McAloon, 2014).

\subsection{Bioactive compounds}

Extraction of ascorbic acid was performed in agreement with Odriozola-Serrano et al. (2007), with modifications. Every $100 \mathrm{mg}$ lyophilized tomato sample was mixed in $5 \mathrm{~mL}$ $4.5 \%$ metaphosphoric acid. The mixture was homogenized and centrifuged at $3220 \times g$ for $15 \mathrm{~min}$ at $4{ }^{\circ} \mathrm{C}$. The supernatant was filtered by a Millipore $0.45 \mu \mathrm{m}$ filter and injected into an HPLC-RID apparatus with a C18 column. Identification of ascorbic acid in samples was performed by reference standards (Sigma Aldrich).

Phenolic compounds were extracted and identified by the method proposed by Scaglioni et al. (2014), with adaptations. Five hundred mg of lyophilized sample was homogenized with $20 \mathrm{~mL}$ ethanol $80 \%$ in a horizontal shaker for $10 \mathrm{~min}$. The extract was filtered by Whatman no. 4 filter paper and the volume was completed until $25 \mathrm{~mL}$ ethanol $80 \%$. Content of ethanol-soluble phenols was determined by the Folin-Ciocalteau reagent by a spectrophotometer at $750 \mathrm{~nm}$; concentration was estimated by a standard curve of gallic acid (from 0 to $25 \mu \mathrm{g} \cdot \mathrm{mL}^{-1}$ ). The phenolic acid profile was carried out by an HPLC (Shimadzu, Tokyo, Japan, CLASS-M10A) coupled with a DAD detector and $\mathrm{C}_{18}$ column $(4.6 \times 250 \mathrm{~mm}, 5 \mathrm{mg}$; Discovery, USA). The elution flow rate was $0.7 \mathrm{~mL} \cdot \mathrm{min}^{-1}$ at $35{ }^{\circ} \mathrm{C}$ with the use of methanol and acid water ( $1 \%$ acetic acid) as the mobile phase in the ratio of 20:80 (v/v) for $25 \mathrm{~min}$; absorbance was determined at 280 and $320 \mathrm{~nm}$ (Scaglioni et al., 2014). Phenolic acids were identified by comparison to retention time of reference standards obtained from Sigma Aldrich: caffeic, chlorogenic, p-coumaric, ferulic, gallic, p-hydroxibenzoic, protocatecoic, syringic and vanillic acids. Quantification of phenolic acids was carried out by individual analytical curves.

Determination of flavonoids was performed by the method proposed by Santos-Buelga et al. (2012), with adaptations. The mixture was analysed by HPLC (Shimadzu, Tokyo, Japan, CLASS-M10A) coupled with a DAD detector and a $\mathrm{C}_{18} 100$ Kromasil $5 \mu \mathrm{m}(4.6 \times 150 \mathrm{~mm})$ column, operated at a flow rate $\mathrm{p} 0.8 \mathrm{~mL} \cdot \mathrm{min}^{-1}$ at $35^{\circ} \mathrm{C}$, mobile phase acidified water (A) (formic acid $0.1 \%$ ) and acetonitrile (B) in gradient. The chromatographic run was $30 \mathrm{~min}$ and absorbance signals were determined at 320 and $370 \mathrm{~nm}$. Identification and quantification were carry out by comparison of the retention time and analytical curve of catechin, quercetin and rutin (Sigma Aldrich).

Carotenoids were extracted in agreement with RodriguezAmaya \& Kimura (2004). Every 0.1 g lyophilized tomato sample was mixed with $5 \mathrm{~mL}$ petroleum ether. The mixture was shaken in an ultrasonic bath for $5 \mathrm{~min}$ and then vortexed for $1 \mathrm{~min}$. The supernatant was collected and the volume was made up to $10 \mathrm{~mL}$ with petroleum ether. Determination of total carotenoids was carried out at 450 and $470 \mathrm{~nm}$ with $\beta$-carotene as the reference standard curve. Petroleum ether was evaporated and the residue was resuspended in mobile phase for the chromatographic evaluation. Individual carotenoids were analysed by HPLC (Shimadzu, Tokyo, Japan, CLASS-M10A) coupled with a DAD detector, in agreement with the method proposed by Cipolatti et al. (2015). Identification of compounds was performed by comparing standard retention time and wavelength absorption spectra and purity of separation of every carotene, they were quantified by molar absorptivity: 3450 and 2592 respectively.

\subsection{Antioxidant activity}

Antioxidant activity of phenolic and carotenoid extracts was determined in ethanol solutions, whose dilutions were adapted 
to the sensitivity of each method, to infer the inhibition in 50\% of the oxidative process by antioxidant compounds in samples.

Determination of the free radical scavenging DPPH $\bullet$ was performed by a UV-vis spectrophotometer (Kasuaki, IL226, São Paulo, SP) at $515 \mathrm{~nm}$, with $0.5 \mathrm{~mL}$ methanol, $3 \mathrm{~mL} \mathrm{DPPH}$ methanolic solution $\left(5.2 \times 10^{-5} \mathrm{~mol}^{-\mathrm{L}^{-1}}\right), 0.5 \mathrm{~mL}$ extract of phenolic compounds $\left(0.6,1.2\right.$ and $\left.1.8 \mu \mathrm{g} \cdot \mathrm{mL}^{-1}\right)$ and carotenoids (250, 500 and $\left.750 \mu \mathrm{g} \cdot \mathrm{mL}^{-1}\right)$. The reaction mixture was kept at room temperature in the dark and the change from purple to yellow was measured after $30 \mathrm{~min}$. Ability to eliminate free radicals was expressed as percentage inhibition, considering the absorbance of the control (without any extract).

The radical ABTS was generated by the oxidation of $7 \mathrm{mM}$ ABTS with $2.45 \mathrm{mM}$ potassium persulphate; the mixture was kept in the dark for $16 \mathrm{~h}$ at room temperature. Solutions with the radical were diluted in ethanol to concentrations that resulted in absorbance ranging from 0.2 to 0.7 at $734 \mathrm{~nm}$. Extracts of phenolic compounds $\left(0.7,1.4\right.$ and $\left.2 \mu \mathrm{g} . \mathrm{mL}^{-1}\right)$ and carotenoids (285,6 and $857 \mu \mathrm{g} \cdot \mathrm{mL}^{-1}$ ) and $3 \mathrm{~mL}$ diluted ABTS were added to the reaction medium. Absorbance was measured at $734 \mathrm{~nm}$ after a 30-min reaction.

The hydroxyl radical was generated by oxidation of hydrogen peroxide in the presence of $\mathrm{Fe}^{2+}$ (Rossi et al., 2013). Thus, $0.5 \mathrm{~mL} 9 \mathrm{mM}$ iron sulphate was added to $0.5 \mathrm{~mL} 9 \mathrm{mM}$ hydrogen peroxide, $0.5 \mathrm{~mL}$ phenolic extract $\left(0.04,0.1\right.$ and $\left.0.2 \mu \mathrm{g} . \mathrm{mL}^{-1}\right)$, carotenoid extract $\left(125,250\right.$ and $\left.375 \mu \mathrm{g} \cdot \mathrm{mL}^{-1}\right)$ and $6.5 \mathrm{~mL}$ distilled water. Stirring was performed manually for $10 \mathrm{~s}$ and the mixture rested at $25^{\circ} \mathrm{C}$ for $10 \mathrm{~min}$, followed by the addition of $0.5 \mathrm{~mL}$ $9 \mathrm{mM}$ salicylic acid and reaction at $25^{\circ} \mathrm{C}$ for $30 \mathrm{~min}$. Absorbance of the solution was determined by a spectrophotometer at $510 \mathrm{~nm}$.

\subsection{Statistical analysis}

The analysis of variance (ANOVA) was applied to compare results of the composition, followed by the Tukey's test at $95 \%$ confidence, by the Statistica 7.0 program. The multivariate analysis was performed by the PAST software program, to apply the PCA to the data set (phenolic compounds, carotenoids and antioxidant activity).

\section{Results and discussion}

\subsection{Physical and chemical properties of samples}

Samples of commercial tomato varieties used by this study were produced by hybrid seeds that were developed to improve technological properties and agronomic characteristics, by comparison with their conventional analogues. They include resistance to fungi and insects, prolongation of post-harvest life and characteristics that are suitable for processing purposes.

Organoleptic characteristics, such as color, taste and aroma, were reached by a combination that allows fruit to be considered ripe and chemical compounds that are related to these properties follow different metabolic pathways (Guillon et al., 2017). The sugar-organic acid ratio and color are associated with ripe tomatoes; therefore, their determination can provide objective signs of their maturation degree (Beauvoit et al., 2014; Figàs et al., 2015). In this study, Khaki and Cherry tomato samples showed higher sugar/organic acid ratio than other samples; it implies that they reach the maturity index faster than other varieties. Croma $\mathrm{a}^{\star}$ represents change from green (-) to red $(+)$, while Croma $b^{*}$ is related to yllow. Tomato samples had high yellow intensity. Fruit that had similar maturity indicators were lyophilized to stabilize and concentrate components to improve sensitivity of analytical techniques. Table 1 shows the range of the maturity indicators adopted to classify fruit in a stage, besides their chemical properties. The highest total pectin content $(47.3 \%)$ was found in Cherry tomato samples, followed by Long Life ones (37.4\%). Cherry tomato samples may have exhibited higher pectin content due to their morphological and structural organization, which was determined genetically. Therefore, the Cherry variety is the best source of soluble fiber, a functional property. The highest $\mathrm{pH}$ was found in Cherry and Italian tomato samples. $\mathrm{pH}$ values of the Cherry variety were comparable to the ones mentioned by Misra et al. (2014) and Rodriguez-Lafuente et al. (2010), in different countries. The fact suggests that high $\mathrm{pH}$ is a varietal characteristic.

Fructose, glucose, sucrose and arabinose contents were determined. However, only fructose and glucose could be quantified, because detection limits of the other sugars were below the one of the methods. Fructose and glucose are the main sugars reported by other studies, as well as sucrose, which is found in smaller amounts (Gómez et al., 2009). Studies have suggested that sucrose is not detectable due to its acid invertase activity (Beauvoit et al., 2014; Figàs et al., 2015). Besides, sucrose is the main form of sugar translocation in tomato plants (Coyago-Cruz et al., 2019); it may explain why glucose and fructose were found at approximately equal amounts in tomatoes, while sucrose concentration was very low. Tomatoes in the full ripening stage exhibited $80 \mathrm{mg}$. $\mathrm{g}^{-1}$ fructose and $280 \mathrm{mg}$. $\mathrm{g}^{-1}$ glucose, while samples that were not considered ripe showed $100 \mathrm{mg}$. $\mathrm{g}^{-1}$ fructose and $400 \mathrm{mg}$. $\mathrm{g}^{-1}$ glucose. Values of this sugar in the samples were higher and did not allow classification into fully ripe and unripe. Some researchers justified that fructose and glucose contents in ripe fruit can result from low incidence

Table 1. Maturation index and chemical composition of tomato samples.

\begin{tabular}{|c|c|c|c|c|}
\hline Composition & Long life & Italian & Khaki & Cherry \\
\hline Moisture (\%) & $94.9^{\mathrm{a}}$ & $94.2^{\mathrm{a}}$ & $94.2^{\mathrm{a}}$ & $94.6^{\mathrm{a}}$ \\
\hline $\operatorname{Ash}^{*}(\%)$ & $8.7^{\mathrm{a}}$ & $9.2^{\mathrm{a}}$ & $10.0^{\mathrm{b}}$ & $6.1^{\mathrm{c}}$ \\
\hline Protein $^{*}(\%)$ & $10.7^{\mathrm{a}}$ & $12.0^{\mathrm{a}}$ & $13.6^{\mathrm{a}}$ & $11.7^{\mathrm{a}}$ \\
\hline Pectin Soluble* (\%) & $0.2^{\mathrm{a}}$ & $0.1^{c}$ & $0.1^{\mathrm{a}}$ & $0.3^{\mathrm{a}}$ \\
\hline Pectin Insolublel $^{\star}(\%)$ & $37.2^{\mathrm{a}}$ & $29.3^{\mathrm{ab}}$ & $20.4^{\mathrm{b}}$ & $47.0^{c}$ \\
\hline $\operatorname{Acidity}^{\star}\left(\mathrm{mg} \cdot \mathrm{g}^{-1}\right)$ & $0.9^{\mathrm{ab}}$ & $1.0^{\mathrm{a}}$ & $0.8^{\mathrm{b}}$ & $0.5^{c}$ \\
\hline $\mathrm{pH}$ & $4.54^{\mathrm{a}}$ & $4.73^{\mathrm{b}}$ & $4.39^{c}$ & $4.71^{\mathrm{b}}$ \\
\hline Glucose (mg.g $\left.{ }^{-1}\right)$ & $170.0^{\mathrm{a}}$ & $195.0^{\mathrm{b}}$ & $151.2^{\mathrm{c}}$ & $150.0^{c}$ \\
\hline Fructose $\left(\mathrm{mg} \cdot \mathrm{g}^{-1}\right)$ & $230.0^{\mathrm{a}}$ & $247.5^{\mathrm{a}}$ & $213.7^{\mathrm{b}}$ & $200.0^{\mathrm{b}}$ \\
\hline AR/acidity & 444.4 & 442.0 & 364.0 & 350.0 \\
\hline $\mathrm{Fe}^{\star}\left(\mu \mathrm{g} \cdot \mathrm{g}^{-1}\right)$ & $25.8^{\mathrm{b}}$ & $29.8^{\mathrm{a}}$ & $20.5^{\mathrm{c}}$ & $22.3^{\mathrm{d}}$ \\
\hline $\operatorname{Mn}^{*}\left(\mu \mathrm{g} \cdot \mathrm{g}^{-1}\right)$ & $16.6^{c}$ & $23.4^{\mathrm{a}}$ & $22.7^{\mathrm{b}}$ & $16.5^{c}$ \\
\hline $\mathrm{Cu}^{*}\left(\mu \mathrm{g} \cdot \mathrm{g}^{-1}\right)$ & $16.5^{\mathrm{c}}$ & $58.1^{\mathrm{a}}$ & $27.6^{\mathrm{b}}$ & $16.5^{c}$ \\
\hline $\mathrm{Ca}^{*}\left(\mu \mathrm{g} \cdot \mathrm{g}^{-1}\right)$ & $152.8^{\mathrm{d}}$ & $267.0^{\mathrm{b}}$ & $329.5^{\mathrm{a}}$ & $243.1^{c}$ \\
\hline Croma a & $12.5^{\mathrm{b}}$ & $17.0^{\mathrm{a}}$ & $17.2^{\mathrm{a}}$ & $11.0^{\mathrm{b}}$ \\
\hline Croma b & $66.1^{\mathrm{ab}}$ & $63.5^{\mathrm{ab}}$ & $72.3^{\mathrm{a}}$ & $35.0^{c}$ \\
\hline
\end{tabular}

*Values expressed as dry basis. $\mathrm{AR}=$ reducing sugar. Letters subscribed in the same line indicate differences among tomato samples $(\mathrm{p}<0.05)$. 
of light during growth in the field, since luminosity affects photosynthesis, which determines sugar storage.

Food quality is related to its content and type of minerals that contribute to taste, appearance, texture and stability, as well as its nutritional value (Fernandes et al., 2019; Nascimento et al., 2020). However, minerals in fruit are affected by environmental factors (Hernández Suárez et al., 2007; Watanabe et al., 2015). Contents of $\mathrm{Fe}, \mathrm{Mn}, \mathrm{Cu}$ and $\mathrm{Ca}$ were evaluated by this study, since they have agronomic importance regarding plant metabolism (Table 1) and can contribute to human health (Bauer et al., 2011). There was significant difference in mineral contents in the tomato samples, but all of them proved to be promising sources of $\mathrm{Ca}, \mathrm{Fe}$ and $\mathrm{Cu}$. Contents of $\mathrm{Fe}, \mathrm{Mn}$ and $\mathrm{Cu}$ were higher in the Italian variety while the Ca content was higher in Khaki samples. Regarding carbohydrate composition, pectin and fructose contents were high in Cherry and Italian varieties, respectively. In this context, every variety can contribute to human health through its chemical components with specific effects. Pectin and fructose contents can contribute to control glycemic index.

\subsection{Functional properties of samples}

Tomatoes and their products are recommended because of their antioxidant activity, which is generally attributed to carotenoids, mainly lycopene, phenolic compounds and ascorbic acid (Choi et al., 2014). The first step to infer about functionality in every tomato variety was to determine the level of ascorbic acid and profiles of carotenoids and phenolic compounds (Table 1). Ascorbic acid plays an important role in several biochemistry processes, such as photosynthesis, growth regulation and senescence. It is a cofactor for enzymes and affects the expression of genes involved in defence and hormonal signalling pathways (Asensio et al., 2019; Huang et al., 2005). Similar amounts of ascorbic acid were found in all varieties of tomato under investigation. Asensio et al. (2019) found lower values of ascorbic acid than the ones found by this study (from 0.025 to $0.1 \mathrm{mg}$. $\mathrm{g}^{-1}$ ); they justified it by stating that tomatoes were grown in a greenhouse.

Tomatoes are considered the main suppliers of lycopene in the human diet. $\beta$-carotene is a pigment found in photosynthetic tissues; however, its concentration decreases at high ripening degree, which is typically accompanied by lycopene accumulation. Lycopene was found at high concentrations (Table 2), mainly in Cherry and Long Life samples. This behavior is consistent with resulting color parameters. Although Croma a is similar for both, Croma b in Long life was two-fold the value of Cherry, as consequence of the inverse relation between their $\beta$-carotene concentrations. Fattore et al. (2016) found $78.6 \mathrm{mg} . \mathrm{g}^{-1}$ lycopene, which is comparable to the levels that were also reported by other authors (Leonardi et al., 2000; Raffo et al., 2002); all were higher than the ones found by this study. Some factors, such as ripening and growth stages, may influence carotenoid content (Coyago-Cruz et al., 2019). A study that evaluated lycopene content in tomatoes grown in greenhouses found that samples of tomatoes grown in the field had higher lycopene content than the latter. It shows that the synthesis of lycopene is inhibited by exposure to intense solar radiation (Asensio et al., 2019). The low lycopene content found by this study may result from the fact that tomatoes were grown in field conditions.
Secondary metabolites of free phenolic families are produced as defence agents of fruit, reflect plant stress and their production is mainly a genetic characteristic. Consequently, every variety had its own characteristic distribution of phenolic families (Table 3). All samples had similar contents of phenolic acids, but their ratios were different. Levels of ferulic, gallic and vanillic acids were below detection limits. p-coumaric acid was detected only in the Italian variety $\left(9.0 \mu \mathrm{g} . \mathrm{g}^{-1}\right)$, while syringic acid was only found in Cherry samples $\left(141.5 \mu \mathrm{g} . \mathrm{g}^{-1}\right)$. Chlorogenic and caffeic acids predominated in the Cherry variety.

In two Cherry tomato varieties (Summerbrix and Lazarino), Coyago-Cruz et al. (2017) found hydroxybenzoic, coumaric, caffeic, chlorogenic and gallic acids, besides the flavonoid quercetin. They observed significant differences in contents of these compounds in relation to the ripening stage. Contents of coumaric, caffeic and chlorogenic acids decreased by $48 \%$, $52 \%$ and $20 \%$, respectively, in tomato samples that were not fully ripe. High phenolic compound contents were also related to the radiation that reached fruit. This study cannot reach any conclusion concerning this issue because samples were collected as consumers do, in markets. Although the sugar/organic acid ratio and color were adopted as maturity indicators to mitigate the effect of maturity on the composition, the environmental condition could not be controlled. However, it is the real situation in the diet of people who consume this fruit as a source of functional compounds. Regarding flavonoids (Table 3), fruit characterized

Table 2. Free phenolic compounds, carotenoids and ascorbic acid of tomato samples.

\begin{tabular}{lcccc}
\hline $\begin{array}{c}\text { Tomato } \\
\text { Varieties }\end{array}$ & $\begin{array}{c}\text { B-carotene } \\
\left(\mathrm{mg} \cdot \mathrm{g}^{-1}\right)\end{array}$ & $\begin{array}{c}\text { Licopene } \\
\left(\mathrm{mg} \cdot \mathrm{g}^{-1}\right)\end{array}$ & $\begin{array}{c}\text { Free } \\
\text { phenolic } \\
\left(\mathrm{mg} \cdot \mathrm{g}^{-1}\right)\end{array}$ & $\begin{array}{c}\text { Ascorbic } \\
\text { acid }\left(\mathrm{mg} \cdot \mathrm{g}^{-1}\right)\end{array}$ \\
\hline Longlife & $0.16^{\mathrm{b}}$ & $15.0^{\mathrm{c}}$ & $31.6^{\mathrm{b}}$ & $3.3^{\mathrm{c}}$ \\
Italian & $0.55^{\mathrm{a}}$ & $10.2^{\mathrm{b}}$ & $34.4^{\mathrm{c}}$ & $3.3^{\mathrm{c}}$ \\
Khaki & $0.17^{\mathrm{b}}$ & $10.5^{\mathrm{b}}$ & $42.5^{\mathrm{a}}$ & $4.2^{\mathrm{a}}$ \\
Cherry & $0.04^{\mathrm{c}}$ & $34.1^{\mathrm{a}}$ & $35.1^{\mathrm{c}}$ & $2.7^{\mathrm{b}}$ \\
\hline
\end{tabular}

Letters subscribed in the same column indicate differences among tomato samples $(\mathrm{p}<0.05)$.

Table 3. Profile of phenolic compounds of tomato samples.

\begin{tabular}{lcccc}
\hline \multicolumn{1}{c}{ Phenolic acids } & $\begin{array}{c}\text { Longlife } \\
\left(\mu \mathrm{g} \cdot \mathrm{g}^{-1}\right)\end{array}$ & $\begin{array}{c}\text { Italian } \\
\left(\mu \mathrm{g}^{-1}\right)\end{array}$ & $\begin{array}{c}\text { Khaki } \\
\left(\mu \mathrm{g} \cdot \mathrm{g}^{-1}\right)\end{array}$ & $\begin{array}{r}\text { Cherry } \\
\left(\mu \mathrm{g}^{-1}\right)\end{array}$ \\
\hline Caffeic & $<\mathrm{LOQ}$ & 9.6 & 32.0 & 104.7 \\
Clorogenic & $<$ LOQ & 21.3 & 49.5 & 575.1 \\
p-cumaric & $<$ LOQ & 9.0 & $<$ LOQ & $<$ LOQ \\
Ferulic & $<$ LOQ & $<$ LOQ & $<$ LOQ & $<$ LOQ \\
Gallic & $<$ LOQ & $<$ LOQ & $<$ LOQ & $<$ LOQ \\
p-hydroxybenzoic & 22.1 & 8.9 & $<$ LOQ & 5.4 \\
Protocatecoic & 36.8 & 118.6 & 121.1 & 47.6 \\
Siringic & $<$ LOQ & $<$ LOQ & $<$ LOQ & 141.5 \\
Vanillic & $<$ LOQ & $<$ LOQ & $<$ LOQ & $<$ LOQ \\
Catechin & 89.1 & 100.4 & 83.8 & 548.8 \\
Quercetin & 67.3 & 92.2 & 72.6 & 96.8 \\
Rutin & 60.6 & 46.2 & 25.2 & 19.2 \\
\hline
\end{tabular}

LOQ = quantification limit. Caffeic, clorogenic, p-cumaric, p-hydroxybenzoic, protocatecoic, vanilic, quercetin, rutin (LOQ $=5 \mathrm{ng} \cdot \mathrm{mL}^{-1}$ ); Ferulic, siringic $\left(\mathrm{LOQ}=10 \mathrm{ng} \cdot \mathrm{mL}^{-1}\right)$; Galic $\left(\mathrm{LOQ}=20\right.$ ng. $\left.\mathrm{mL}^{-1}\right)$; Catequin $\left(\mathrm{LOQ}=30\right.$ ng. $\left.\mathrm{mL}^{-1}\right)$. 
by a high peel/pulp ratio, such as Cherry tomatoes, contain high content of phenolic compounds; catechin $\left(548.8 \mu \mathrm{g} . \mathrm{g}^{-1}\right)$ was the predominant one, by comparison with the others.

Quercetin is consistently reported as the most abundant flavonoid in tomato, followed by naringenin (Fattore et al., 2016). The highest level of quercetin was found in Cherry tomatoes $\left(96.8 \mu \mathrm{g} . \mathrm{g}^{-1}\right)$. The highest content of rutin was found in Long Life tomatoes $\left(60.6 \mu \mathrm{g} . \mathrm{g}^{-1}\right)$, while the lowest one was exhibited by Cherry tomatoes $\left(19.2 \mu \mathrm{g} . \mathrm{g}^{-1}\right)$.

\subsection{Antioxidant activity}

Regular consumption of tomato products has been correlated with reduction in susceptibility to disorders, such several types of cancer and cardiovascular diseases (García-Hernández et al., 2018; Navarro-González et al., 2018). They are caused by oxidative processes that are not triggered by the same mechanism. Thus, activities of chemical compounds to mitigate damage must also be different. Antioxidant ability of an antioxidant compound to inactivate radical propagation is determined by its chemical structure and reactivity to affect oxidative processes in vivo. The main factor of beneficial effects is the reduction potential of chemical groups, rather than the antioxidant concentration of a source.

In vitro procedures have been adopted to evaluate antioxidant potential of chemical groups in different oxidation-reduction conditions (Zielinski et al., 2020). Considering that every tomato variety had its own profile of reduction compounds in carotenogenic and phenolic extracts, the reduction potential was evaluated by different methods. Antioxidant activity was expressed as the concentration $\left(\mu \mathrm{g} \cdot \mathrm{mL}^{-1}\right)$ of carotenoids or phenolic compounds that were necessary to promote $50 \%$ inhibition (IC50) of the oxidative process (Table 4). This strategy allows to compare antioxidant effects because every method is based on a kinetic condition which is specific for its mechanism and stoichiometry. Therefore, to compare inhibition as percentages may distort the real capacity that extracts from every variety have to mitigate oxidative damage. The lowest IC50 represents the most efficient extract to protect health.

Phenolic extracts were efficient to inhibit radicals peroxyl (DPPH), oxidative reactions mediated by metalic compounds (ABTS) and by the radical hydroxyl. However, carotenogenic extracts showed effect only when high extract concentrations were used. Considering that carotenoids are hydrophobic compounds, these results were expected for these methods, whose reactions

Table 4. Antioxidant activities of phenolic and carotenoid extracts expressed as IC50 (ug. $\mathrm{mL}^{-1}$ ).

\begin{tabular}{lcccccccc}
\hline & \multicolumn{3}{c}{ Phenolic compounds } & & \multicolumn{3}{c}{ Carotenoids } \\
\cline { 1 - 4 } \cline { 7 - 8 } $\begin{array}{c}\text { Tomato } \\
\text { Varieties }\end{array}$ & DPPH & ABTS & $\begin{array}{c}\text { Radical } \\
\text { hydroxil }\end{array}$ & DPPH & ABTS & $\begin{array}{c}\text { Radical } \\
\text { hydroxil }\end{array}$ \\
\hline Longlife & $1.7^{\mathrm{a}}$ & $1.1^{\mathrm{a}}$ & $0.07^{\mathrm{b}}$ & & $357^{\mathrm{d}}$ & $1667^{\mathrm{b}}$ & $162^{\mathrm{a}}$ \\
Italian & $1.5^{\mathrm{b}}$ & $1.1^{\mathrm{a}}$ & $0.11^{\mathrm{a}}$ & & $446^{\mathrm{b}}$ & $1000^{\mathrm{c}}$ & $156^{\mathrm{a}}$ \\
Khaki & $1.8^{\mathrm{a}}$ & $1.2^{\mathrm{a}}$ & $0.03^{\mathrm{c}}$ & & $400^{\mathrm{c}}$ & $1670^{\mathrm{b}}$ & $140^{\mathrm{b}}$ \\
Cherry & $1.5^{\mathrm{b}}$ & $1.1^{\mathrm{a}}$ & $0.11^{\mathrm{a}}$ & & $555^{\mathrm{a}}$ & $2500^{\mathrm{a}}$ & $160^{\mathrm{a}}$ \\
\hline
\end{tabular}

Letters subscribed in the same column indicate differences among tomato samples $(\mathrm{p}<0.05)$. occur in polar media, even though they have been applied by other researchers to infer antioxidant potential of carotenoids.

Phenolic compounds are the main inhibitors of antioxidant activity, mainly in Italian tomatoes, which inhibited DPPH and ABTS radicals, and in Long Life ones, for the $\mathrm{OH}$ radical. In these tomatoes, phenolic compounds stood out for protocatecoic acid and catechin concentration, indicating that they may be responsible for the inhibition of free radicals released by any mechanism. Italian and Cherry tomatoes stood out for their antioxidant activities, even though they did not differ in their free phenolic concentrations. Therefore, the multivariate statistical technique, the PCA, was carried out to explain the correlation among the different parameters that affected functional properties of tomatoes.

\subsection{Principal component analysis}

The data set for the first PCA was a matrix $4 \mathrm{x} 8$ (rows $\mathrm{x}$ columns) where the rows were the tomato variety and the columns were the phenolic compounds, carotenoid and its antioxidant activities. The PCA (Figure 1) showed that $84.7 \%$ of variability was explained by component $1(61.5 \%)$ and component $2(23.2 \%)$. Phenolic compounds had high correlation (R:0.94) with the capture of the ABTS radical, the main indicator which is responsible for the inhibition of radical peroxyl propagation. Nevertheless, carotenoid concentration had an inverse relation with radical ABTS and DPPH inhibition. This trend had previously been observed when antioxidant potential of extracts was determined.

To identify phenolic acid that had the highest effect on antioxidant activity of tomato extracts, a new PCA was performed (Figure 2). The data set for the second PCA was a matrix $4 \times 12$ (rows $\mathrm{x}$ columns) where the rows were the tomato variety and the columns were the phenolic acids and antioxidant activities. The PCA showed that $79.8 \%$ of result variability was explained by component $1(51.5 \%)$ and component $2(28.3 \%)$. In this case, protocatecoic acid better explained antioxidant activity. Among phenolic acids, the protocatecoic one is more correlated with the DPPH radical (0.84). Therefore, it is mainly responsible for preventing the oxidation mechanism promoted by oxygen radicals. Profiles of phenolic compounds and carotenoids found in tomato samples better reinforce their antioxidant activity, rather than their total content of carotenoids.

\section{Conclusion}

The Cherry tomato variety is the best source of soluble fiber, because it stands out for pectin, sugar/acidity ratio and lycopene content. Concerning essential mineral components, $\mathrm{Cu}$ and Ca had the highest levels in the samples. Phenolic compounds better explain the antioxidant potential than carotenoids. The PCA showed that protocatecoic acid and quercetin are most closely related with antioxidant activity of samples, while there was negative correlation with carotenoids. Regarding carotenoid and antioxidant properties, Italian and Cherry tomatoes stood out. Considering samples grown in field conditions and available in markets, both Cherry and Italian are the best sources of functional compounds among varieties that are common in the human diet. 


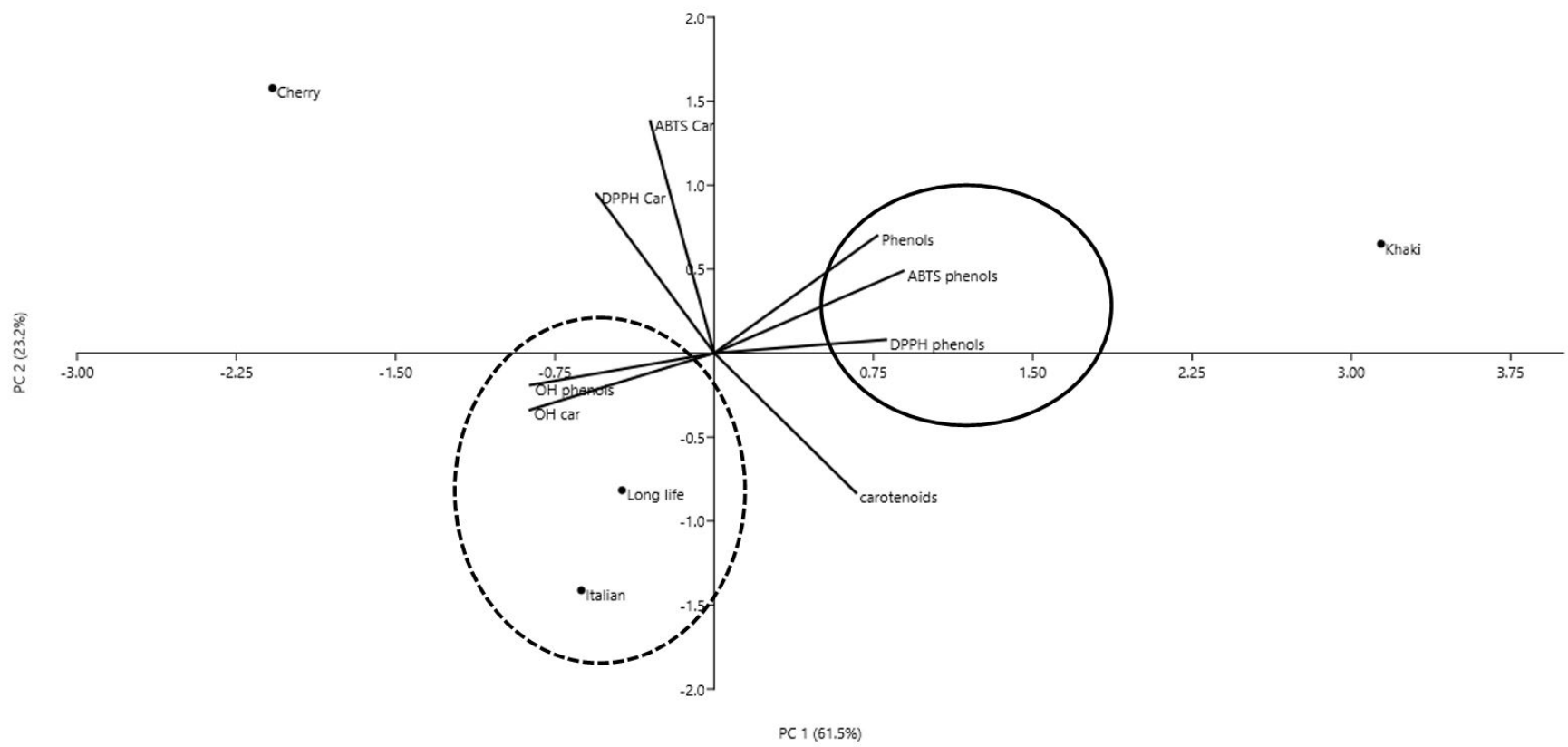

Figure 1. PCA analysis of antioxidant compounds. $\mathrm{Car}=$ carotenoid; $\mathrm{OH}=$ Radical Hydroxil.

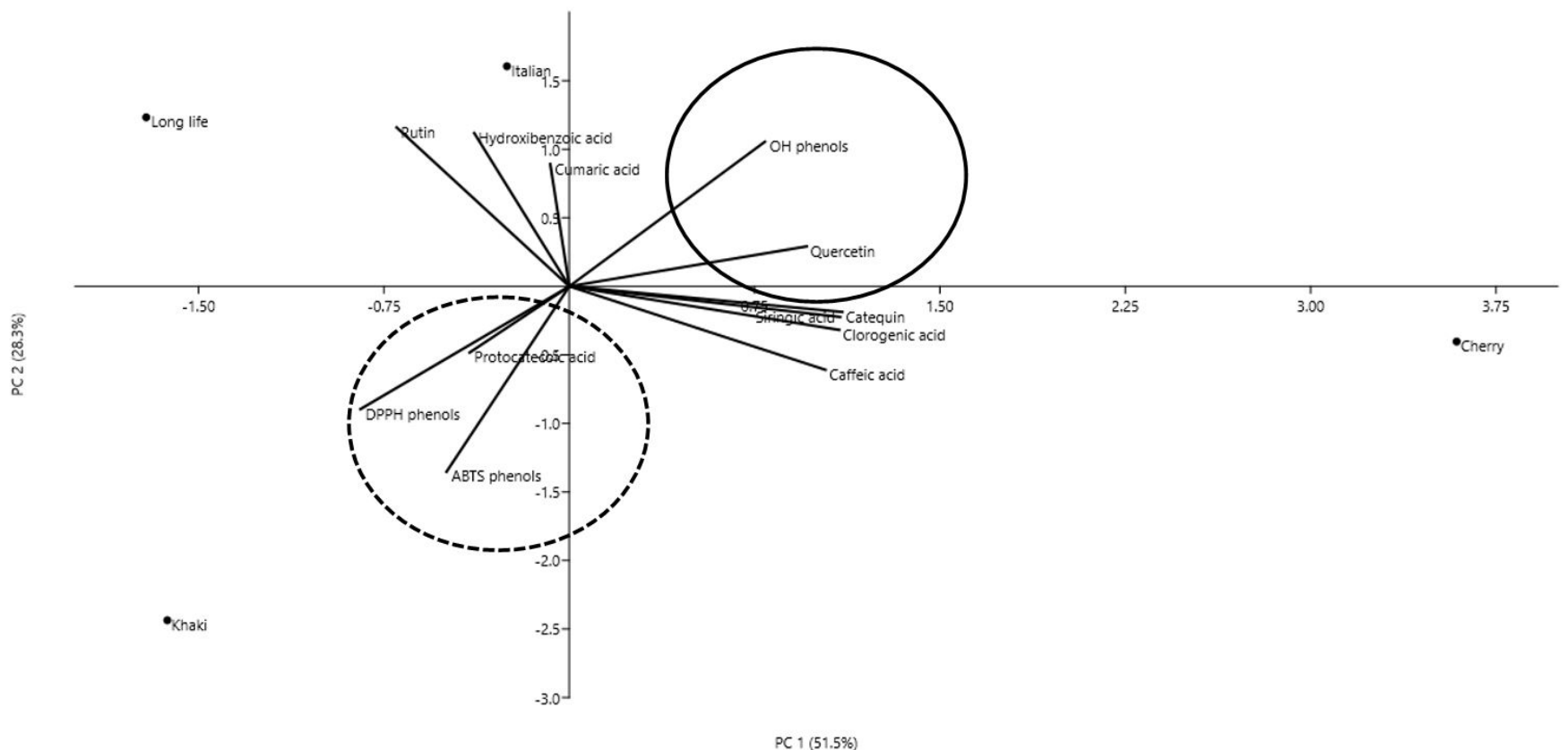

Figure 2. PCA analysis of the profile of phenolic compounds. $\mathrm{OH}=$ Radical Hydroxil.

\section{References}

Asensio, E., Sanvicente, I., Mallor, C., \& Menal-Puey, S. (2019). Spanish traditional tomato: effects of genotype, location and agronomic conditions on the nutritional quality and evaluation of consumer preferences. Food Chemistry, 270, 452-458. http://dx.doi.org/10.1016/j. foodchem.2018.07.131. PMid:30174071.

Association of Official Analytical Chemists - AOAC. (2000). Official methods of analysis (17th ed.). Arlington: AOAC.

Bauer, P., Elbaum, R., \& Weiss, I. M. (2011). Calcium and silicon mineralization in land plants: transport, structure and function.
Plant Science, 180(6), 746-756. http://dx.doi.org/10.1016/j. plantsci.2011.01.019. PMid:21497710.

Beauvoit, B. P., Colombié, S., Monier, A., Andrieu, M.-H., Biais, B., Bénard, C., Chéniclet, C., Dieuaide-Noubhani, M., Nazaret, C., Mazat, J.-P., \& Gibon, Y. (2014). Model-assisted analysis of sugar metabolism throughout tomato fruit development reveals enzyme and carrier properties in relation to vacuole expansion. The Plant Cell, 26(8), 3224-3242. http://dx.doi.org/10.1105/tpc.114.127761. PMid:25139005.

Borguini, R. G., \& Silva Torres, E. A. F. (2009). Tomatoes and tomato products as dietary sources of antioxidants. Food Reviews International, 25(4), 313-325. http://dx.doi.org/10.1080/87559120903155859. 
Commission Internationale de l'Eclairage - CIE (1986). Colorimetry. Publication CIE 15.2 (2nd ed.). Wien, Austria: Commission International de l'Éclairage.

Choi, S. H., Kim, D. S., Kozukue, N., Kim, H. J., Nishitani, Y., Mizuno, M., Levin, C. E., \& Friedman, M. (2014). Protein, free amino acid, phenolic, $\beta$-carotene, and lycopene content, and antioxidative and cancer cell inhibitory effects of 12 greenhouse-grown commercial cherry tomato varieties. Journal of Food Composition and Analysis, 34(2), 115-127. http://dx.doi.org/10.1016/j.jfca.2014.03.005.

Cipolatti, E. P., Bulsing, B. A., Sa, C. S., Burkert, C. A. V., Badiale-Furlong, E., \& Burkert, J.F. M. (2015). Carotenoids from Phaffia rhodozyma: antioxidant activity and stability of extracts. African Journal of Biotechnology, 14(23), 1982-1988. http://dx.doi.org/10.5897/AJB2015.14682.

Coyago-Cruz, E., Corell, M., Moriana, A., Hernanz, D., Stinco, C. M., \& Meléndez-Martínez, A. J. (2017). Effect of the fruit position on the cluster on fruit quality, carotenoids, phenolics and sugars in cherry tomatoes (Solanum lycopersicum L.). Food Research International, 100, 804-813. http://dx.doi.org/10.1016/j.foodres.2017.08.002. PMid:28873753.

Coyago-Cruz, E., Corell, M., Moriana, A., Mapelli-Brahm, P., Hernanz, D., Stinco, C. M., Beltrán-Sinchiguano, E., \& Meléndez-Martínez, A. J. (2019). Study of commercial quality parameters, sugars, phenolics, carotenoids and plastids in different tomato varieties. Food Chemistry, 277, 480-489. http://dx.doi.org/10.1016/j.foodchem.2018.10.139. PMid:30502174.

Fattore, M., Montesano, D., Pagano, E., Teta, R., Borrelli, F., Mangoni, A., Seccia, S., \& Albrizio, S. (2016). Carotenoid and flavonoid profile and antioxidant activity in "Pomodorino Vesuviano" tomatoes. Journal of Food Composition and Analysis, 53(1238), 61-68. http:// dx.doi.org/10.1016/j.jfca.2016.08.008.

Fernandes, M. de F. L., Moraes, S. M., Sousa, P. H. M., Magalhães, C. E. C., Almeida, M. M. B., \& Silva, M. G. V. (2019). Characterization of leaves used in infusion preparation grown in northeastern Brazil by chemometric methods based on their multi-elemental composition. Food Science and Technology, 39(Suppl. 1), 309-315. http://dx.doi. org/10.1590/fst.00718.

Figàs, M. R., Prohens, J., Raigón, M. D., Fita, A., García-Martínez, M. D., Casanova, C., Borràs, D., Plazas, M., Andújar, I., \& Soler, S. (2015). Characterization of composition traits related to organoleptic and functional quality for the differentiation, selection and enhancement of local varieties of tomato from different cultivar groups. Food Chemistry, 187, 517-524. http://dx.doi.org/10.1016/j. foodchem.2015.04.083. PMid:25977058.

García-Hernández, J., Hernández-Pérez, M., Peinado, I., Andrés, A., \& Heredia, A. (2018). Tomato-antioxidants enhance viability of L. reuteri under gastrointestinal conditions while the probiotic negatively affects bioaccessibility of lycopene and phenols. Journal of Functional Foods, 43, 1-7. http://dx.doi.org/10.1016/j.jff.2017.12.052.

Gómez, P., Ferrer, M. Á., Fernández-Trujillo, J. P., Calderón, A., Artés, F., Egea-Cortines, M., \& Weiss, J. (2009). Structural changes, chemical composition and antioxidant activity of cherry tomato fruits (cv. Micro-Tom) stored under optimal and chilling conditions. Journal of the Science of Food and Agriculture, 89(9), 1543-1551. http://dx.doi. org/10.1002/jsfa.3622.

Granato, D., Nunes, D. S., \& Barba, F. J. (2017). An integrated strategy between food chemistry, biology, nutrition, pharmacology, and statistics in the development of functional foods: a proposal. Trends in Food Science \& Technology, 62, 13-22. http://dx.doi.org/10.1016/j. tifs.2016.12.010.

Guillon, F., Moïse, A., Quemener, B., Bouchet, B., Devaux, M. F., Alvarado, C., \& Lahaye, M. (2017). Remodeling of pectin and hemicelluloses in tomato pericarp during fruit growth. Plant Science, 257, 48-62. http://dx.doi.org/10.1016/j.plantsci.2017.01.008. PMid:28224918.

Hernández Suárez, M., Rodríguez Rodríguez, E. M., \& Díaz Romero, C. (2007). Mineral and trace element concentrations in cultivars of tomatoes. Food Chemistry, 104(2), 489-499. http://dx.doi.org/10.1016/j. foodchem.2006.11.072.

Huang, D., Ou, B., \& Prior, R. L. (2005). The chemistry behind antioxidant capacity assays. Journal of Agricultural and Food Chemistry, 53(6), 1841-1856. http://dx.doi.org/10.1021/jf030723c. PMid:15769103.

Johnston, D. B., \& McAloon, A. J. (2014). Protease increases fermentation rate and ethanol yield in dry-grind ethanol production. Bioresource Technology, 154, 18-25. http://dx.doi.org/10.1016/j.biortech.2013.11.043. PMid:24378840.

Leonardi, C., Ambrosino, P., Esposito, F., \& Fogliano, V. (2000). Antioxidative activity and carotenoid and tomatine contents in different typologies of fresh consumption tomatoes. Journal of Agricultural and Food Chemistry, 48(10), 4723-4727. http://dx.doi. org/10.1021/jf000225t. PMid:11052724.

Li, N., Li, Z., Huang, W., Habib, S., Yang, L., \& Hu, G. (2017). Functional characterization of SISAHH2 in tomato fruit ripening. Frontiers of Plant Science, 8, 1-12. http://dx.doi.org/10.3389/fpls.2017.01312.

McCready, R. M., \& McComb, E. A. (1952). Extraction and Determination of Total Pectic Materials in Fruits. Analytical Chemistry, 24(12), 1986-1988. http://dx.doi.org/10.1021/ac60072a033.

Misra, N. N., Keener, K. M., Bourke, P., Mosnier, J. P., \& Cullen, P. J. (2014). In-package atmospheric pressure cold plasma treatment of cherry tomatoes. Journal of Bioscience and Bioengineering, 118(2), 177182. http://dx.doi.org/10.1016/j.jbiosc.2014.02.005. PMid:24650730.

Nascimento, M. M., Jesus, R. M., Santos, H. M., Silva Junior, A. L. S., Campos, N. M. C. O., Silva, E. G. P., \& Lôbo, I. P. (2020). Quality pattern evaluation of frozen soursop pulps: an assessment based on chemical composition and chemometric analysis. Food Science and Technology, 40(2), 508-516. http://dx.doi.org/10.1590/fst.04919.

Navarro-González, I., García-Alonso, J., \& Periago, M. J. (2018). Bioactive compounds of tomato: Cancer chemopreventive effects and influence on the transcriptome in hepatocytes. Journal of Functional Foods, 42, 271-280. http://dx.doi.org/10.1016/j.jff.2018.01.003.

Odriozola-Serrano, I., Hernández-Jover, T., \& Martín-Belloso, O. (2007). Comparative evaluation of UV-HPLC methods and reducing agents to determine vitamin C in fruits. Food Chemistry, 105(3), 1151-1158. http://dx.doi.org/10.1016/j.foodchem.2007.02.037.

Raffo, A., Leonardi, C., Fogliano, V., Ambrosino, P., Salucci, M., Gennaro, L., Bugianesi, R., Giuffrida, F., \& Quaglia, G. (2002). Nutritional value of cherry tomatoes (Lycopersicon esculentum cv. Naomi F1) harvested at different ripening stages. Journal of Agricultural and Food Chemistry, 50(22), 6550-6556. http://dx.doi.org/10.1021/ jf020315t. PMid:12381148.

Rodriguez-Amaya, D. B., \& Kimura, M. (2004). HarvestPlus handbook for carotenoid analysis. Washington: HarvestPlus.

Rodriguez-Lafuente, A., Nerin, C., \& Batlle, R. (2010). Active paraffinbased paper packaging for extending the shelf life of Cherry tomato. Journal of Agricultural and Food Chemistry, 58(11), 6780-6786. http://dx.doi.org/10.1021/jf100728n. PMid:20476770.

Rossi, M., Caruso, F., Antonioletti, R., Viglianti, A., Traversi, G., Leone, S., Basso, E., \& Cozzi, R. (2013). Scavenging of hydroxyl radical by resveratrol and related natural stilbenes after hydrogen peroxide attack on DNA. Chemico-Biological Interactions, 206(2), 175-185. http://dx.doi.org/10.1016/j.cbi.2013.09.013. PMid:24075811.

Santos-Buelga, C., Carvalho, A. M., Ferreira, I. C. F. R., Dueñas, M., \& Barros, L. (2012). Characterization of phenolic compounds in flowers 
of wild medicinal plants from Northeastern Portugal. Food and Chemical Toxicology, 50(5), 1576-1582. http://dx.doi.org/10.1016/j. fct.2012.02.004. PMid:22342808.

Scaglioni, P. T., de Souza, T. D., Schmidt, C. G., \& Badiale-Furlong, E. (2014). Availability of free and bound phenolic compounds in rice after hydrothermal treatment. Journal of Cereal Science, 60(3), 526-532. http://dx.doi.org/10.1016/j.jcs.2014.08.005.

Ulewicz-Magulska, B., \& Wesolowski, M. (2019). Total phenolic contents and antioxidant potential of herbs used for medical and culinary purposes. Plant Foods for Human Nutrition, 74(1), 61-67. http:// dx.doi.org/10.1007/s11130-018-0699-5. PMid:30374852.

Vallverdú-Queralt, A., Jáuregui, O., Medina-Remón, A., \& LamuelaRaventós, R. M. (2012). Evaluation of a method to characterize the phenolic profile of organic and conventional tomatoes. Journal of
Agricultural and Food Chemistry, 60(13), 3373-3380. http://dx.doi. org/10.1021/jf204702f. PMid:22380972.

Watanabe, M., Ohta, Y., Licang, S., Motoyama, N., \& Kikuchi, J. (2015). Profiling contents of water-soluble metabolites and mineral nutrients to evaluate the effects of pesticides and organic and chemical fertilizers on tomato fruit quality. Food Chemistry, 169, 387-395. http://dx.doi.org/10.1016/j.foodchem.2014.07.155. PMid:25236242.

Zielinski, A. A. F., Alberti, A., Bona, E., Bortolini, D. G., Benvenutti, L., Bach, F., Demiate, I. M., \& Nogueira, A. (2020). A multivariate approach to differentiate yerba mate (Ilex paraguariensis) commercialized in the Southern Brazil on the basis of phenolics, methylxanthines and in vitro antioxidant activity. Food Science and Technology, 40(3), 645-652. http://dx.doi.org/10.1590/fst.15919. 